\title{
Performance Evaluation of UK Acquiring Companies in the Pre and Post-Acquisitions Periods
}

\author{
Khurshid Ali ${ }_{\star}$ \\ Zeeshan Khan ${ }^{2}$ \\ Numan Khan ${ }^{3}$ \\ Abdul-Hamid Ibrahim Alsubaie ${ }^{4}$ \\ Fazal Subhan ${ }^{5}$ (D) \\ Moumen Kanadil ${ }^{6}$
}

${ }^{1}$ Salford University Manchester, UK

Pakistan Institute of Development Economics (PIDE)

${ }^{3}$ Center for Management \& Commerce, University of Swat

${ }^{4}$ University of Liverpool, UK

Subject Specialist Economic Department of Elementary Secondary Education, KP, PK

Salford University Manchester, UK.

\begin{abstract}
This paper has two objectives: first, it examines the financial performance of twenty UK based acquiring companies over the period of five years (2009-2013) using financial ratios of Liquidity, Profitability and Solvency in order to empirically determine whether there is any significant financial performance changes in the operation of the underlying companies as a result of acquisitions. Both average ratio and paired t-test analysis have been conducted. The analysis concludes that none of the ratios proved statistical significance which shows that the underlying acquisitions did not influence changes in the financial performance of the acquiring companies. The paper also examines whether shareholders make short-term gain while opting for acquisitions by analyzing stocks return over 58 days window period i.e. 29 days prior to acquisition announcement and 29 days after acquisition announcement by applying CAPM model and AAR and CAAR analysis. The analysis concludes that none of the results show statistical significance which further asserts that UK shareholders do not make gain in the short-term as a result of the acquisition activities they have undertaken.
\end{abstract}

Keywords: Financial Performance, Liquidity, Profitability, Solvency, Acquisition, CAPM, AAR, CAAR.

\section{Contents}

1. Introduction

2. Literature Review

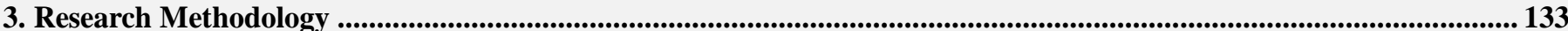

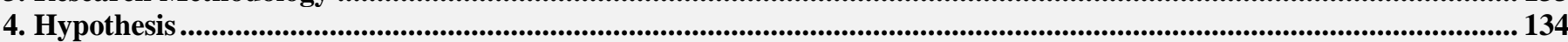

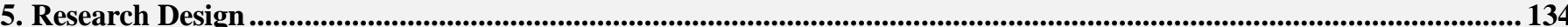

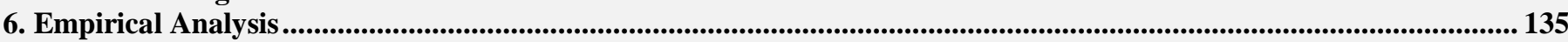

7. Discussion ...un 135

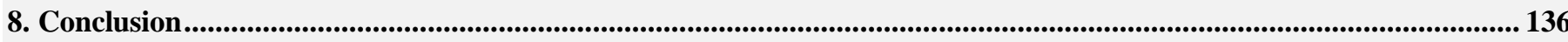

References

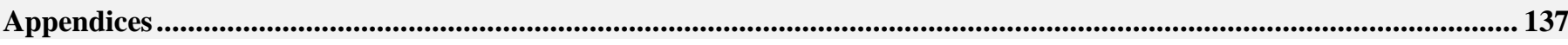

Citation | Khurshid Ali; Zeeshan Khan; Numan Khan; Abdul-Hamid Ibrahim Alsubaie; Fazal Subhan; Moumen Kanadil (2016). Performance Evaluation of UK Acquiring Companies in the Pre and Post-Acquisitions Periods. Asian Journal of Economics and Empirical Research, 3(2): 130-138.

DOI:

$\operatorname{ISSN}(\mathbf{E})$ 10.20448/journal.501/2016.3.2/501.2.130.138 Crossref

This work is licensed under a Creative Commons Attribution 3.0 License (cc) EY

Contribution/Acknowledgement: All authors contributed to the conception and design of the study.

Funding:

Competing Interests:

Transparency:

This study received no specific financial support.

History:

Ethical:

Publisher:

The authors declare that they have no conflict of interests.

The authors confirm that the manuscript is an honest, accurate, and transparent account of the study was reported; that no vital features of the study have been omitted; and that any discrepancies from the study as planned have been explained. Received: 19 August 2016/ Revised: 24 September 2016/ Accepted: 30 September 2016/ Published: 13 October 2016 This study follows all ethical practices during writing. Asian Online Journal Publishing Group 


\section{Introduction}

Companies from across the world are increasingly looking to mergers and acquisitions (M\&As) as one of the most appropriate means for strategic expansion into other markets (Reynolds and Teerikangas, 2016). As M\&As provide greater opportunities for companies to enter international markets to build new competencies and capabilities as well as to reach their global clients (Singla et al., 2012). Among developed countries UK's companies in particular showed greater interest in M\&As across the world which is evident from the acquisition of 7,026 companies by UK acquirer companies during 1996 to 2005 while the number of deals further raised to 1008 during 2006 (Ahammad and Glaister, 2008). Moreover, the post-recession (2007/08) scenario shows an increasing trend in merger and acquisition as revealed by Bloomberg (2015) that $\$ 467$ billion worth of M\&As deals have been announced in the first quarter of 2015 which is predicted to even over take pre-recession growth witnessed during 2007; majority of the deals were executed in either USA or UK which can be attributable to the free market and corporate friendly practices in both of the economies. However, one third of all M\&As deals announced during 2014 in Europe collapsed at the final stages of execution where some of the biggest deals even failed to meet the market expectations. For example, Pfizer's \$53 billion bid for AstraZeneca made a lot of buzz in the market but soon the US drug maker's takeover passion fell flat in front of the UK Takeover Panel's rules (The Telegraph, 2014).

Throughout the history of M\&As, UK in particular remained a breeding ground for M\&As activities as evident from research literature that during 1995 to 2005 UK companies had the highest merger and acquisitions deals in the USA, Europe and Asia Pacific region (Ahammad and Glaister, 2008). This trend was fueled by many determinants however the more encouraging determinant of M\&A for UK companies was to acquire more market share in order to gain long term financial objectives as well as to maintain global presence in order to remain competitive (Jansson et al., 1994). Even in the post-recession period the UK economy shows higher surge in M\&As activities as in the first quarter of $2014 £ 37.5$ billion worth of M\&A deals were struck which is by far the largest development since 2007. The UK's healthcare sector witnessed the largest M\&As activities accounted for 26.9 percent of the preceding figure where the sale of GlaxoSmithKline's oncology division to Novartis for $£ 8.6$ billion was one of the mega mergers (Raconteur, 2014). The surge in M\&As deals is contributable to the rather healthy economic indicators prevalent in the UK as institutions and investors alike looking for avenues to generate higher return on their long kept capital. Uddin and Boateng (2011) has empirically supported this by arguing that GDP, money supply and share price have statistically significant influence on the level of UK's mergers and acquisitions activities across the world.

In spite of the surge in M\&As across the world, it is still ambiguous whether M\&As result in value creation for shareholders. As many researchers advocate that agency problems overwhelm and often ignore the objectives of M\&As to create shareholders value (Danbolt, 2004). The management of bidding company often pursue their own utility maximization through acquisition that may include increasing their own power, status and salary etc. Other researchers such as Firth (1991) and Bliss and Rosen (2001) cited by Danbolt (2004) also support the argument that cross border mergers and acquisitions often found to be benefiting managers rather than shareholders as managers of the bidding company often overestimate the value of the economic benefit of the proposed merger resulting in extra cost to acquiring companies. Nevertheless, substantial research finding also support the argument that merger and acquisition lead to value creation for shareholders. Looking at a relatively broader aspect of merger and acquisition, it is always proved to be a gateway to adapt firm to the external macro level changes such as the ever increasing economic integration of nations, cultural homogenization, and the liberalization of trade and capital markets; thus M\&As may not benefit in short-term however the long term benefit is inevitable to come (Elango, 2006). Through acquisition firm gain quick control of an established firm in the host country as is evident by the example of Tesco acquisition of Star Bazaar stores in India from Tata Group that enabled Tesco to quickly gear up its corporate strategy according to local market needs through which Tesco penetrated with greater speed than would have been possible through Greenfield operation. However, there can be pitfalls as often argued by researchers such as over valuation of the target firm, increased cost as a result of cultural dissimilarities, acquisition of undesirable assets, and successful integration can lead to drastic consequences. Moreover, certain portion of policymaker in the UK do believe that M\&As do not benefit UK economy that came out more evidently during the Kraft Foods bid for Cadbury Plc during 2009 where the deal faced considerable resistance. As a result the UK takeover panel presented a number of changes to UK takeover codes aimed at protecting the interest of the target firm. The failure of Pfizer and AstraZeneca $\$ 53$ billion deal is the result of UK's protectionist policy that can severely damage UK's reputation of being a corporate friendly market famous for high value M\&As deals.

Similarly, the short-term value gain for shareholders as a result of merger and acquisition is also being widely debated in the literature, however, handful of researchers such as Hassan et al. (2004); Du and Boateng (2014) and Dutordoir et al. (2014) empirically defend that M\&As result in short-term gain for shareholders as they argue that capital markets react to acquisition announcement positively that in turn result in abnormal gain for underlying stocks. In any case value creation through M\&As remains central to every M\&A deal. However, value creation at the same time is attributable to several factors i.e. effective global competition, growth potential of the hosting market, favorable input cost, improved distribution network, lower cost of capital, regulatory infrastructure of host country and favorable exchange rate etc (Picot, 2002 cited by Ray and Ray (2014). However, in the longer run most of the mergers deals fail from shareholders' perspective when measured against the stock price because the abnormal gain in the short run is quickly incorporated in the security price. Moreover, the post-acquisition phase often involve complex operations that lead to considerable delay resulting in the erosion of net present value of cash flow that causes negative impact on the overall process of M\&As underlying plan resulting in total failure (Businessweek, 2002, cited by MacDonald (2005)). The M\&A deal between Rover and BMW well explains the scenario where the deal was prematurely cancelled because the post-merger integration process took several years which destroyed the anticipated shareholders value instead of gaining from the merger while Daimler and Chrysler also met the same fate (Kursten, 2008). This leads to the understanding that shareholders value creation through M\&As is wide area to be researched in order to determine whether shareholders value creation in the short term can be attained. 


\section{Literature Review}

Value creation through Mergers and Acquisition (M\&A), in the context of UK's bidders and target firms, has been discussed widely in the literature; however, whether it creates value for UK shareholders in the short-term is either supported or ruled out by various findings. As evident by the findings of Uddin and Boateng (2009) who investigate cross border acquisitions of 373 UK's acquiring firms during 1994 to 2003 in order to determine the factors influencing the short term performance, argue that UK's bidding firms do not earn positive abnormal return in the short-run by examining stock price performance of 373 UK bidding firms involved in cross border mergers and acquisition during 1994 to 2003. They further argue that the absence of abnormal return through M\&A can be contributable to the competitive nature of UK's market where any new information is being quickly incorporated in the security price. However, contrary to this, Chanmugam et al. (2005) by writing an investigative article to measure the performance of 350 post-merger integration engagement aimed at determining common grounds for successful $M \& A$, argue that the entire $M \& A$ process hardly create value for shareholders because the valuation process for any potential M\&A has become much more familiar as it (M\&A) leads to almost similar synergies and therefore the market does not react abnormally. However, they argue that value creation can still be achieved by focusing on several areas i.e. treating $\mathrm{M} \& \mathrm{~A}$ as holistic process, giving emphasis on value creation rather than integration and minimizing the time required to execute merger and acquisition.

Another study conducted by Delaney and Wamuziri (2004) who investigate the financial performance of UK's construction companies that have carried out any merger or acquisition deals in order to empirically examine the impact of merger announcement on both acquiring and merging firms stocks performance, reveals that shareholders of target firms earn abnormal positive returns prior to the announcement of an acquirer firms bid; however, it does not last long enough. The study further reveals that the bidder firms found to be having greater returns in the longer period following the merger announcement mainly after forty days period. This shows that market does not react instantly to the bidders' firms stocks prices because for market post acquisition scenario seems to be much more important that appropriately judges the success or failure of any underlying M\&A; as Goergen and Renneboog (2003) who investigate the short-term wealth effects of large (intra)European takeover bids to determine whether short-term gain can be achieved through M\&A, argue that in most of the cases the shareholders of target firms demand a premium over and above the current stock price as a condition to accept the acquisition offer, therefore, the acquiring firm would require efficient managerial strategy to cover the cost of the M\&A as well as create value for the shareholders. This puts greater emphasis on the acquirer firm capabilities to generate increased cash flow stream that exceeds the acquisition bid premium. This is well evident by the findings of Schoenberg and Bowman (2010) who, by proposing a typology of acquisition value creation logics and recommending implementation process based on governance, cost and knowledge variables, argue that value creation in the merger and acquisition process is entirely dependent on the organizational capabilities of the acquirer to cover successfully the post implementation phase. According to Schweiger and Very (2003) who investigating the complex relationship between valuation, pricing, strategic objectives, synergies and integration in the M\&A process, argue that it is the successful integration of M\&A that leads to value creation as previous records show that majority of the M\&As proved to be unsuccessful in terms of financial expectations which is contributable to lack of strategic fit or inadequate due diligence. Similarly, Ray and Ray (2013) who propounding a different connotation of synergy for cross border M\&As, also argue that value creation can only be achieved through successful implementation of post-acquisition integration plan. This shows that M\&A is holistic process where in addition to incremental cost other aspects such as over valuation, potential synergies etc should be examined prudently.

In order to expand and reap the benefits of synergies companies across the world strive hard to make acquisition deals more than ever before as is evident by Bloomberg findings that reveals that $\$ 467$ billion worth of M\&A deals have been announced in the first quarter of 2015 while it predicts that if the deals continued with this pace it can beat prerecession period of summer 2007 when M\&A proposals reached to $\$ 933.4$ billion (Bloomberg, 2015) more than fifty percent of the deals occurred in America and Britain where both having open markets for corporate (The Economist, 2014). Nevertheless, one of the senior funds manager (cited by The Economist (2014)) argue that M\&A deals only benefit executives and enrich bankers at the expense of shareholders, as he argues that when firm announce acquisition share prices of the acquiring firm starts to fall because investors fear that the premium they pay could exceed the benefits from the potential synergy. Contrary to this Mckinsey consulting firm argues (cited by The Economist (2014)) that since 2012 share prices of the acquiring firms either remained stable or have risen which certainly leaves a room for further empirical investigation.

In the context of UK market merger and acquisition is being viewed as the major strategic tool through which companies can gain short-term financial gains for shareholders. However, the more encouraging determinant of M\&A for UK companies is to acquire more market share in order to gain long term financial objectives as the findings of Jansson et al. (1994) revealed who carried out investigating the determinants of CBMA of UK manufacturing companies in Europe. As evident from the past literature UK companies had the highest investments in foreign industrialized countries through the acquisition of foreign companies. EU companies in particular were the highest targets for UK companies however between 1995 to 2005 UK companies acquired US firms which accounted for 29 percent of the overall cross border mergers during the mentioned period. Similarly, Asia-Pacific region also remained a third target for the UK firms as argued by Ahammad and Glaister (2008) who investigated the driving forces behind the ever increasing M\&A deals and also reviewed the recent trend of CBMA by UK firms. The UK companies follow standard term i.e. they have acquired manufacturing companies in Europe, Canada and American, however, in the Asia-Pacific region the UK companies concentrated on the acquisition of service sector companies. This shows that expansion through cross border merger and acquisition (CBMA) is much more common for UK companies across the world.

The UK economy in particular shows strong economic recovery indicators since the financial crash in 2007/08 therefore companies position themselves for growth mainly through mergers and acquisition. In the second quarter of $2014 £ 37.5$ billion worth of M\&A deals were struck which is by far the largest development since 2007 witnessed by 
the UK's market. The UK's healthcare sector witnessed the largest M\&A activities accounted for 26.9 percent of the preceding figure where the sale of GlaxoSmithKline's oncology division to Novartis for $£ 8.6$ billion was one of the mega mergers (Raconteur, 2014). According to market analysts cited by Raconteur (2014) surge in mergers and acquisition in the UK's market is contributable to several factors however strong economic growth in particular has played a greater role as the UK's GDP has witnessed a 3 percent growth in the third quarter of 2014 as compared to previous year while the grim economic indicators in the Euro zone, as a result of potential Euro zone breakup, has started to subside that has considerably helped the market to recover. Ian Sale, a managing director at Lloyds Bank commercial banking acquisition's finance, says: "we have seen demand and supply conditions for M\&A improved markedly over the past year. Investors looking for yield, cash-rich trade buyers, a hungry banking sector and private equity houses with funds to deploy have all contributed to a highly liquid market." (Raconteur, 2014).

Nevertheless, value creation as a result of mergers and acquisition still remains an intriguing area as several research findings such as Chanmugam et al. (2005); Kursten (2008); MacDonald (2005) support the idea that most of M\&A deals benefit executives rather than shareholders. However, yet substantial research findings support the idea of value creation for shareholders as a result of mergers and acquisition. As argued by Boyer and Choi (2007) who by investigating the reasons that contribute to the consolidation of financial services industry and also examine some cases of successful and unsuccessful M\&As, argues that synergy or value creation for shareholders is an inevitable result of mergers and acquisition subject to the successful implementation of integration, adequate valuation and limited diversification. Similarly, Kursten (2008) while investigating why shareholders should be prudent when managers assure value gains from a potential synergetic mergers, argue that even synergetic merger cannot guarantee any benefits to shareholders unless the value of the synergy exceed certain level, thus he rules out the idea of shortterm gain for shareholders however he argues that in the longer run shareholders can benefit from synergetic M\&A. That is why MacDonald (2005) while elaborating his viewpoint on shareholders' value creation, argues citing BusinessWeek findings that during 1995 to 2000 majority of the mergers were failure from shareholders point of view when measured against the price of the stock. The study further complements that often the mergers deals were overvalued resulting in compromising shareholders' value creation.

Another study conducted by Hassan et al. (2004) in the context of US pharmaceutical industry which investigates short term abnormal returns of 405 M\&A during 1981 to 2004 finds that abnormal short term gains were witnessed in the case of acquiring companies but overall, except ROA and cash flow improvements in some instances, most of the measures were found to be insignificant statistically. This can be argued that although pharmaceutical companies carry out high volume of transactions to forge M\&A deals mostly often in billions dollars however still do not result in short term gains which cast some doubt on the efficacy of the mergers of large firms. Nevertheless, there are instances where large companies M\&A deals have become success stories as evident from numbers of research findings. As evident by the findings of Du and Boateng (2014) who by investigating the effect of state ownership and institutional influences on value creation through CBMA by Chinese firms using a sample of 468 firms during 1998 to 2011, findings empirically support the argument that CBMA results in short-term gain for shareholders in the context of Chinese acquirer firms that have earned abnormal returns over 10 days event window and founds that Chinese security market reacts positively to acquisition announcement. Moreover, their findings further assert that government and institutions play a decisive role in CBM\&A value creation.

However, value creation cannot be confined to government or institutions role but rely on several variables that lead to value creation for shareholders. The findings of Dutordoir et al. (2014) who by investigating bidding firms' motives for disclosing a synergy forecast when announcing a merger or acquisition, best illustrate the example by proving it empirically that the disclosure of potential synergy information by acquiring firms is being perceived positively by the security market that in turn results in value creation for shareholders in the short-term. Thus it can be argued that value creation is much broader term that requires a holistic approach to ensure value creation rather than relying on predefined variables. That is why Singla et al. (2012) by investigating cross border merger and acquisition on the financial performance of Indian acquiring companies, argue that value creation determinants of CBM\&A such as profitability ratios, cash flow measures and stock market estimates compared to industry peers vary from country to country. In other words, in some countries stock market estimates may trigger value creation but in other country security market may not be efficient enough to reflect the success of a particular M\&A. This is well evident by the findings of Elango (2006) who by investigating the impact of international acquisition announcement on an insurance firm's shareholder's wealth, argue that overseas acquisition were found to be insignificant statistically in terms of market returns which the author contributed to factors i.e. the degree of wealth of the host country, amount of bilateral trade between host and home country, extent of potential liabilities of foreignness (LOF) faced by the firm, and economies of scope. Moreover, some of the M\&A deals may not be meant to create short term shareholders value but rather be aimed for like growing bigger in size or achieving global status in order to ensure long term strategic growth as argued by Singla et al. (2012).

\section{Research Methodology}

A number of researchers have investigated empirically the short-term gain of UK acquiring firms and have also reported statistically significant positive return for UK shareholders Delaney and Wamuziri (2004); Hassan et al. (2004) and Du and Boateng (2014). However, some of the researchers such as Chanmugam et al. (2005); Kursten (2008); MacDonald (2005) do not support that view that M\&As can result in short-term gain for shareholders. Nevertheless, researchers like Dutordoir et al. (2014) and Singla et al. (2012) argue that there are several variables that contribute in the creation of shareholders value as a result of mergers and acquisition deals both in the short and long-term scenarios. Researchers have applied both quantitative and qualitative methods to dig deep into the area whether shareholders benefit from any proposed merger/acquisition deals. However, majority of the researchers such as Singla et al. (2012); Du and Boateng (2014); Hassan et al. (2004) and Delaney and Wamuziri (2004) have carried out quantitative empirical research based on time series data of the respective companies stocks to determine whether there is any influence on the movement of security as a result of merger/acquisition. This study also aims to examine 
the impact of cross border merger and acquisition on the financial performance of UK acquiring companies by using financial ratios i.e. profitability, liquidity and solvency analysis. Moreover, to analyse the immediate impact of cross border merger and acquisition on the UK acquiring companies shareholders' wealth time series data of stocks prices has been analysed through regression analysis.

\section{Hypothesis}

$\mathrm{H}_{0}$ (1): The financial performances of UK acquiring companies do not change significantly after the acquisition compared to their pre-merger/acquisition level.

$\mathrm{H}_{0}$ (2): The shareholders of UK acquiring companies do not gain significant value from mergers and acquisitions activities.

\section{Research Design}

The current study undertakes an empirical research aimed at determining whether merger/acquisition by the UK acquiring companies result in short-term gain for UK shareholders. The study is based on 20 UK based companies from various sectors that have gone through merger/acquisition activities during 2009 to 2013. Prior to this work several researchers such as Uddin and Boateng (2009) have attempted to investigate value creation through M\&As in the context of UK but are conducted in either pre-recessionary period i.e. before 2007 or confined to specific industry such as the work by Delaney and Wamuziri (2004) and Jansson et al. (1994) carried out research work for either UK construction industry or manufacturing industry respectively. Thus, the sample of this study would provide a relatively greater insight of the UK M\&As activities as the sample incorporate leading companies from almost all the UK's industries as well as the sample period covers both the recession period (2009/2011) and period when UK's economy started recovering from the financial recession during 2012 and 2013. Table 1 provides detailed illustration.

In order to assess pre-merger and post-merger impact on companies' performance, a sample of 5 years (20092013) has been selected which consist of 2 years prior to acquisition and 2 years after acquisition coupled with acquisition year in order to assess the pre-merger and post-merger performance of the underlying firms stocks. Out of the twenty sampled companies 4 companies carried out acquisition in 2009 followed by 7 in 2010 and 3 in 2011. One company had acquisition in 2008 and 2 companies had acquisition in 2013.

In order to test the first hypothesis profitability, liquidity, debt and solvency ratios of the sampled companies are calculated. The analysis involves computing the underlying ratios for the period of two years prior to merger and two years after the merger as well as the calculation for the acquiring year. The industry average number has been used to nullify the effect of other factors on corporate performance in the underlying period. These ratios i.e. profitability, liquidity and solvency have been chosen to continue with researchers tradition as many prominent researcher have used these ratios to examine the financial performance of different organizations. As Liu et al. (2013) profitability, solvency and liquidity ratios to examine financial differences between Chinese and Japanese firms; similarly liquidity and profitability ratios have also been used by Borhan et al. (2014) to examine the financial performance of chemical company. Finally, Tan et al. (1997) used profitability, liquidity and solvency ratios among other to measure the financial performance Singapore listed companies. Moreover, in the context of mergers and acquisitions Singla et al. (2012) liquidity, profitability and solvency ratios to investigate the financial performance of Indian acquiring companies using 15 companies over the period of four years i.e. 2005 to 2008. Therefore, based on the wide application of liquidity, profitability and solvency ratios in the literature of measuring financial performance of companies the following ratios have been selected for this study. The ratios are explained as follow;

1. Liquidity ratio: Current assets / Current liabilities

This ratio measures the company's short-term assets, i.e. cash, cash equivalent, marketable securities, receivables and inventory, to determine whether the company can meet its short-term liabilities efficiently. The higher ratio exhibit better liquidity position of the company.

2. Operating profit ratio: operating profit / sales

This ratio measures the level of a company's revenue leftover after paying for variable cost i.e. wages, raw materials etc. A higher operating ratio would indicate that the company is stable enough to service its debt obligation. 3. Debt equity ratio: total liabilities / total assets - total liabilities or net assets

This ratio measures the level of debt a firm has against each dollar it owns. Higher ratio in this instance would pose a considerable for an organization as it would be burdened with greater amount of debt than which can be viewed as unsustainable in the eyes of lenders.

4. Net profit: Profit after tax / sales

This ratio measures the percentage of money a company actually earns per dollar of sales. The higher ratio would indicate that the company has good cost management in place that results in higher net earnings.

5. RONW (return on net worth): profit after tax or Net income / equity

This ratio measures the firm's profitability by revealing the extent of profit the company generates by deploying shareholders' equity. The higher ratio would indicate that company has efficiently deployed its resources to generate more income.

Financial ratios have been used extensively in the literature mainly to measure firms' financial performance such as Samad and Hassan (1999) used financial ratios to measure the financial performance of Malaysian banks. In the context of merger and acquisition Singla et al. (2012) have used financial ratios to determine Indian companies' financial performance both in pre-merger and post-merger periods.

In order to test the second hypothesis, event methodology has been applied. This will measure the reaction of acquirer's companies stocks to the announcement of merger activities in order to determine whether abnormal return can be gained or not. The following equation is being used;

$$
A R_{t}=R_{t}-\mathbf{E}\left(\mathbf{R}_{t}\right)
$$

Where $t=$ day relative to an event, $A_{t}=$ abnormal return on the stocks for the day $t, R_{t}=$ actual return on the security for the day, $E\left(R_{t}\right)=$ estimated rate of return on the security for the day $t$. In order to calculate the estimated 
rate of return of the security capital asset pricing model (CAPM) is being used where a period of 180 days prior to the event window is used for estimating the stocks' beta. Using the equation (1), the abnormal return for all the 20 acquiring firms has been computed for 58 days window period i.e. 29 days prior to the acquisition announcement date and 29 days after the acquisition announcement date. The abnormal return has been summed up for each day in order to determine the pattern of cumulative average abnormal return (CAAR).

\section{Empirical Analysis}

The analysis of prominent financial ratios (see Table 4.1) i.e. liquidity, profitability and solvency ratios indicate no statistical significance both in the pre-merger and post-merger periods. In order to nullify the effect of other factors, although cannot be ruled out entirely, in the industry the ratios are averaged two years before the merger/acquisition and two years after the merger/acquisition.

The five ratios show no statistical significance in any of the periods thus it all leads to the acceptance of first null hypothesis that the post-merger/acquisition financial performance of the UK acquiring companies is not significantly different from pre-merger/acquisition financial performance. The results are consistent with findings of Singla et al. (2012) who, in the context of Indian acquiring companies, found that none of the financial ratios showed statistical significance in the both pre and post-merger periods. Moreover, the analysis of individual companies ratios on yearly and two yearly bases, both in the pre-merger and post-merger periods, also reveals no significant financial performance thus it can be concluded that no abnormalities has been observed in the financial performance of the acquiring companies as a result of merger/acquisition announcement. The average liquidity ratio shows almost equal position in the two years before and two years after the M\&As activities. This shows that acquiring firms' liquidity position has not been affected by the underlying mergers and acquisitions activities. Moreover, debt to equity ratio showed exactly the same pattern in the two years before and after the acquisition. Similarly, operating profit ratio followed the same pattern, however, net profit ratio declined slightly in the two years after the acquisition which can be contributable to the relative rise in expenses as a result of the underlying acquisition. Finally, RONW ratio showed negative trend, almost shrank by 60 percent, in the two years after acquisition which shows that UK shareholders incurred considerable losses as a result of acquisition, however, the same ratio remained stable during the one year after the acquisition which can be contributable to the short span of time where post-acquisition process are still underway while in the longer run such as in the twenty four months period the net present value of cash is being negatively affected because of the prolonged post-integration process that erodes profitability.

To further verify the aforementioned results the paired t-test results (see Table 4.2) reveals that none of the financial ratios are significant statistically as the mean difference of the two periods i.e. pre and post-mergers are minimal which suggest there was no significant improvement in the financial performance after the acquisition. Moreover, the RONW ratio although shows negative effect after the acquisition however is not statistically significant as evident from the t-test results. Thus, the first null hypothesis can be accepted.

The standard deviation shows that beta, calculated for 30 days period, remained stable for all the companies both in the pre-merger and post-merger 58 day window period except Trifast, Brady, Optos Dead and OMG where the standard deviation of the respective companies' beta showed negative trend. Thus, it can be argued that on average the underlying companies stocks did not react abnormally to changes in the market or to the announcement of the acquiring companies' merger/acquisition news. Hence, this leads to the acceptance of second null hypothesis that there is no significant impact on the acquiring companies' shareholders' wealth due to the announcement of cross border merger/acquisition news. Moreover, the paired t-test results for the stocks shows no statistical significance over the 58 days window period that further confirms that no significant gain was observed as a result of acquisitions announcement by the underlying companies.

The results of average abnormal return (AAR) (see Figure 4.1) shows that prior to acquisition announcement AAR remained negative for almost over two weeks period; however only sharp positive increase of .81 and .84 percent were observed one week prior to acquisition announcement date but soon followed by negative trend. Similarly, after the announcement of acquisition date the AAR suddenly goes in an upward direction reaching .96 percent following for over two weeks with slight variation followed by a negative trend in the last week of the 29 days window period in the post-acquisition time. This, however, shows that as a result of acquisition activities market react positively to the changes that in turn result in short-term gain for shareholders as argued by Delaney and Wamuziri (2004). Thus, shareholders of the acquiring firms had marginal gain only for a short while after acquisitions.

However, the cumulative average abnormal return (CAAR) (see figure 1) shows negative trend for the entire period and even reached to -5.04 percent after the acquisition announcement. This shows that over the 58 days period shareholders incurred considerable losses rather than gain. the relative longer negative trend of CAAR in both pre and post-acquisition announcement period can be contributable to the relative grim economic indicators prevalent in the UK market during 2009 to 2013 where capital market in particular found to be more sceptic to such announcements following the collapse of Northern Rock, RBS as well as the bailout of big financial institutions in the UK triggered by economic recession during 2007/08. The outcomes of CAAR are inconsistent with the results of Singla et al. (2012) cumulative average abnormal return where CAAR of the Indian acquiring firms showed almost marginal gain instead. Moreover, the results of this study are also inconsistent with the findings of Delaney and Wamuziri (2004) who argue, in the context of UK construction companies, that shareholders of bidding firms earn abnormal positive returns prior to the announcement of an acquirer firms bid; however, it does not last long enough as was the case in this study findings of ARR where the gain reached to .96 percent but for a short period of time.

\section{Discussion}

Greater portion of the literature review examined until now empirically support the arguments that shareholders of the bidding firms do not gain from the acquisition process as well as they argue that bidding firms do not seem to improve their financial position as a result of acquisitions. The results of this study in the context of UK's acquiring 
companies also support the findings of the earlier studies. The examination of financial ratios mainly liquidity, profitability and solvency over the two years window period before acquisition and after acquisition report no significant improvement as well as the acquiring year also shows no financial improvement. The insignificance of the results can be contributable to number of reasons. Uddin and Boateng (2009) giving one potential reason by explaining that UK has competitive capital market that instantly absorb any new information therefore shareholders cannot make abnormal returns as a result of acquisition announcement instead the market closely observe the activities therefore, as evident from the results, no financial improvement is observed in the short-term i.e. two years after the acquisition. Secondly, Chanmugam et al. (2005) explain that the non-value creation of mergers/acquisitions can be contributable to the relative mature process of M\&As as every company uses identical process to undertake M\&As activities that often lead to overestimating the potential synergies that in turn leads to financial losses rather than gain. As evident by the prevalent literature that during implemental or integration phase most of the M\&As cost increases as a result of complex structural and cultural issues. Thus, the companies under investigation might also have the met the same of incurring post-mergers/acquisitions problems. Thirdly, the results of this study can also be contributable to the sample period (2009 to 2013) as the UK economy was passing through the worst ever recessionary period during this time that brought the entire economic activities to almost a standstill. As evident from the findings of Uddin and Boateng (2011) that GDP, money supply and share price has significant impact on the CBM\&As activities in the UK. They further argue that managers need to time acquisitions activities with macrolevel variables, i.e. the relative upward movement of GDP, in order to make value for shareholders.

The investigation of the underlying companies stocks through CAPM model over the 58 days window period also proved to be insignificant statistically i.e. the stocks observed an insignificant abnormal return over the underlying 58 days window period. This can also be the result of the relative downward trend witnessed in the overall stocks market during the sampled period as grim economic indicators were prevalent in the UK, Europe and USA in particular. Moreover, mergers/acquisitions activities are being carried out at a larger scale than ever before as $\$ 467$ billion worth of M\&A deals have been announced in the first quarter of 2015 only (Bloomberg, 2015) therefore market closely observe the underlying cost of M\&As, the potential synergies and the successful implementation of the integration process. Furthermore, it becomes a growing concern in the capital markets across the world that acquisition result in the sudden fall of acquiring companies stocks as investors fear that the potential synergy as a result of M\&As may be of less economic value than the premium they pay to the target firms. Hence, the outcomes of CAMPM in this study may also be the result of the general perception about M\&As prevalent in the market.

Contrary to the preceding results, AAR (average abnormal return) exhibited positive abnormal gain one week prior to acquisition date which although did not last long but yet shows that market receive the acquisitions news positively that in turn give rise to shareholders return in the short-run. Moreover, in the post-acquisition announcement period abnormal return was seen positive for almost over two weeks with slight variation that again reaffirm the general notions that the UK acquiring companies shareholders gain in the short-term as a result of acquisitions activities.

Nevertheless, the results of cumulative average abnormal return (CAAR) of this study is also consistent with the proceeding results i.e. both in pre and post-acquisition period CAAR a continuous negative trend has been observed in the stocks return and that shows that market did not react positively to the announcement of acquisition deals as supported by majority of the literature. Thus the findings of Delaney and Wamuziri (2004) that UK shareholders gain from acquisition activities in the short-term can be ruled out in the context of this study. The outcomes of the CAAR in this study is also inconsistent with the findings of Singla et al. (2012) who witnessed abnormal cumulative return in the post-announcement period in the context of Indian acquiring companies.

\section{Conclusion}

The analysis of financial ratios of profitability, liquidity and solvency of the acquiring firms reveals no significant change. In other words neither in the pre-acquisition period nor in the post-acquisition period has no significant financial improvement been observed in the financial performance of the UK acquiring companies. The ratios were also analysed using paired t-test analysis to nullify the effect of other industrial variables but none of the ratios found to be statistically significant. This can mainly be the result of the general economic downward of the UK economy during 2009 to 2013 as a result of financial recession where big corporations in particular suffered severe financial problems across developed countries' markets. That is why the acquiring companies' pre-acquisition financial position could be the result of financial recession while the post-acquisition financial performance can be contributable to the relative premium share price they pay to the target companies that result in higher cost which can only be recovered in the longer period subject to acquiring companies' management efficiency (Goergen and Renneboog, 2003).

Moreover, the analysis of the acquiring companies stocks through CAPM model over 58 days window period, i.e. 29 days prior to acquisition and 29 days after the acquisition, reveals no abnormal average return during all the 58 days event window further confirm that no significant gain was made by the UK shareholders as a result of the underlying acquisitions activities. This can be contributable to the fact that greater number of M\&As are being carried out in the UK therefore the market do not react instantly to the news as acquisitions are often being viewed by investors as long term process that takes considerably longer to result in profitability (Chanmugam et al., 2005). Secondly, during the sampled period most of the companies' stocks experienced downward trend as a result of financial recession in the UK hence this could have greater influence on the analysis. Moreover, the cumulative average abnormal return (CAAR) of the acquiring companies showed consistent negative return over the entire period of 58 days window period before and after acquisition announcement. However, AAR result showed positive trend prior to acquisition announcement and after acquisition period but did not last long but yet it can be established, at least in the context of AAR analysis, that shareholders had a marginal gain over the short-term period before and after acquisitions. The outcomes of the CAAR in this study however are not consistent with the findings of several 
researchers such as Delaney and Wamuziri (2004); Boyer and Choi (2007); Hassan et al. (2004) and Singla et al. (2012) who empirically support that mergers/acquisitions result in short-term gain for shareholders.

\section{References}

Ahammad, F.M. and W.K. Glaister, 2008. Recent trends in UK cross-border mergers and acquisitions. Management Research News, 31(2): 8698.

Bloomberg, 2015. Smartphones on the beach for London dealmakers sweating M\&A boom. Retrieved from http://www.bloomberg.com/news/articles/2015-08-04/smartphones-on-the-beach-for-london-dealmakers-sweating-m-a-boom [Accessed 8th August 2015].

Borhan, H., N.R. Mohamed and N. Azmi, 2014. The impact of financial ratios on the financial performance of a chemical company. World Journal of Entrepreneurship, Management And Sustainable Development, 10(2): 154-160.

Boyer, C.E. and J.J. Choi, 2007. Mergers and consolidation of financial service firms: Global trends and strategies for value creation. International Financial Review, 7: 393-417.

Chanmugam, R., W. Shill, D. Mann, K. Ficery and B. Pursche, 2005. The intelligent clean room: Ensuring value capture in merger and acqusition. Journal of Business Strategy, 26(3): 43-49.

Danbolt, J., 2004. Target company cross-border effects in acquisitions into the UK. European Financial Management, 10(1): 83-108.

Delaney, F.T. and S.C. Wamuziri, 2004. The impact of mergers and acquisitions on shareholder wealth in the UK construction industry. Engineering, Construction and Architectural Management, 11(1): 65-73.

Du, M. and A. Boateng, 2014. State ownership, institutional effects and value creation in cross-border merger \& acquisitions by Chinese firm. International Business Review, 24(3): 430-442.

Dutordoir, M., P. Rosenboom and M. Vasconcelos, 2014. Synergy disclosures in mergers and acquisitions. International Review of Financial Analysis, 31(January): 88-100.

Elango, B., 2006. When does cross-border acquisition of insurance firms lead to value creation? Journal of Risk Finance, 7(4): 402-414.

Goergen, M. and L. Renneboog, 2003. Value creation in large European mergers and acquisitions. Advances in Mergers and Acquisitions, 2: 97-146.

Hassan, M., K.D. Patro, H. Tuckman and X. Wang, 2004. Do mergers and acquisitions create shareholder wealth in pharmaceuticals industry? International Journal of Pharmaceutical and Healthcare Marketing, 1(1): 58-78.

Jansson, K., M. Kirk-Smith and S. Wightman, 1994. The impact of the single European market on cross-border mergers in the UK manufacturing industry. European Business Review, 94(2): 8-13.

Kursten, W., 2008. Synergies, shareholders value and exchange ratios in value-creating mergers. Managerial Finance, 34(4): $252-261$.

Liu, M.C., G. O'Farrell, K.K. Wei and J.L. Yao, 2013. Ratios analysis comparability between Chinese and Japanese firms. Journal of Asia Business Studies, 7(2): 185-199.

MacDonald, R., 2005. A template for shareholder value creation on M\&As. Strategic Direction, 21(5): 3-10.

Raconteur, 2014. M\&A grows as UK economy recovers. Retrieved from http://raconteur.net/finance/m-and-a-grows-as-uk-economy-recovers [Accessed 8th August 2015].

Ray, G.K. and G.R. Ray, 2013. Cross-border mergers and acquisitions: Modelling synergy for value creation. Advances in Mergers and Acquisitions, 12: 113-134.

Ray, K.G. and S.G. Ray, 2014. Cross-border mergers and acquisitions: Modelling synergy for value creation. Advances in Mergers and Acquisitions (Advances in Mergers and Acquisitions) Emerald Group Publishing Limited, 12: 113-134.

Reynolds, N. and S. Teerikangas, 2016. The international experience in domestic mergers - are purely domestic M\&A a myth. International Business Review, 25(1): 42-50.

Samad, A. and M.K. Hassan, 1999. The performance of Malaysian islamic banks during 1994-1997: An exploratory study. International Journal of Islamic Financial Services, 1(3): 1-14.

Schoenberg, R. and C. Bowman, 2010. Value creation in corporate acquisitions: Linking value creation logic, organizational capabilities and implementation process. Advances in Mergers and Acquisitions, 9(1): 153-176.

Schweiger, M.D. and P. Very, 2003. Creating value through merger and acquisition integration. Advances in Mergers and Acquisitions, 2(1): $1-26$.

Singla, R., A. Saini and R. Sharma, 2012. Cross border mergers and acquisitions: A performance evaluation of Indian acquiring companies. Asia-Pacific Journal of Management, Research and Innovation, 8(2): 127-132.

Tan, M.S.P., C.H. Koh and C.L. Low, 1997. Stability of financial ratios: A study of listed companies in Singapore. Asian Review of Accounting, 5(1): 19-39.

The Economist, 2014. The new rules of attraction. Retrieved from http://www.economist.com/news/business/21632675-latest-boomdealmaking-appears-more-sensible-its-predecessors-valuations-are [Accessed 10th August 2015].

The Telegraph, 2014. Tesco to invest in India. Retrieved from http://www.telegraph.co.uk/finance/personalfinance/expatmoney/10740210/Tesco-to-invest-in-India.html [Accessed 11th August 2015].

Uddin, A. and A. Boateng, 2009. An analysis of short-run performance of cross-border mergers and acquisitions. Review of Accounting and Finance, 8(4): 431-453.

Uddin, A. and A. Boateng, 2011. Explaining the trends in the UK cross-border mergers \& acquisitions: An analysis of macro-economic factors. International Business Review, 20(5): 547-556.

\section{Appendices}

Table-3.1. List of Acquiring Companies

\begin{tabular}{l|l|l|l}
\hline & Companies & & Companies \\
\hline 1 & Smith \& Nephew & 11 & HUNTSWORTH \\
\hline 2 & prudential & 12 & G4S \\
\hline 3 & Advanced Med.SLTB.GP & 13 & ALLOCATE SOFTWARE DEAD \\
\hline 4 & TRIFAST & 14 & NATIONAL EXPRESS \\
\hline 5 & COBHEM & 15 & PEARSON \\
\hline 6 & BRADY & 16 & ULTRA ELECTRONICS HDG \\
\hline 7 & IMMIGINATION TECHNOLOGIES & 17 & INMARSAT \\
\hline 8 & OPTOS DEAD & 18 & ASSOCIATED BRIT. FOODS \\
\hline 9 & OMEGA DIAGNOSTICS GROUP & 19 & HALMA \\
\hline 10 & RSA INSURANCE GROUP & 20 & OMG \\
\hline Source: Samples for the Study through Yahoo Finance and Companies Annual Reports.
\end{tabular}


Table-4.1. Pre and After Results calculation for UK based Companies sampled in this study

\begin{tabular}{l|l|l|l|l|l}
\hline & $\begin{array}{l}\text { Average 2 years } \\
\text { before }\end{array}$ & $\begin{array}{l}\text { Average 1 years } \\
\text { before }\end{array}$ & $\begin{array}{l}\text { Average years } \\
\text { of acquisition }\end{array}$ & $\begin{array}{l}\text { Average 1 years } \\
\text { after }\end{array}$ & $\begin{array}{l}\text { Average 2 years } \\
\text { after }\end{array}$ \\
\hline Liquidity ratio & 1.99682 & 1.96472 & 1.88070 & 1.86611 & 1.80036 \\
\hline Debt profit ratio & 1.25093 & 1.18827 & 1.22486 & 1.09945 & 1.25525 \\
\hline Operating profit ratio & 0.10196 & 0.12138 & 0.10477 & 0.11841 & 0.11976 \\
\hline Net profit ratio & 0.09512 & 0.07966 & 0.07876 & 0.12452 & 0.06264 \\
\hline RONW & 0.12758 & 0.10864 & 0.10951 & 0.11789 & 0.08776 \\
\hline
\end{tabular}

Source: Author's Own Calculation through Excel

Table-4.2. T-Tests and Descriptive Statistics for Pre and After Merger and Acquisition

\begin{tabular}{l|l|l|l|l}
\hline Ratio & Mean & Mean Difference & Standard Deviation & T-Test \\
\hline Liquidity Before & 1.9808 & & 0.0227 & \\
\hline Liquidity After & 1.8332 & -0.1475 & 0.0465 & 0.0563 \\
\hline Dept Equity Before & 1.2196 & & 0.0443 & \\
\hline Debt Equity After & 1.1774 & -0.0422 & 0.1102 & 0.6648 \\
\hline Operating Profit Before & 0.1117 & & 0.0137 & \\
\hline Operating Profit After & 0.1191 & 0.0074 & 0.0010 & 0.4165 \\
\hline Net Profit Before & 0.0874 & & 0.0109 & \\
\hline Net Profit After & 0.0936 & 0.0062 & 0.0438 & 0.8640 \\
\hline RONW Before & 0.1181 & & 0.0134 & \\
\hline RONW After & 0.1028 & -0.0153 & 0.0213 & 0.4809 \\
\hline
\end{tabular}

Source: Author's Own Calculation through Excel

\section{AAR(\%) and CAAR(\%) for the whole sample}

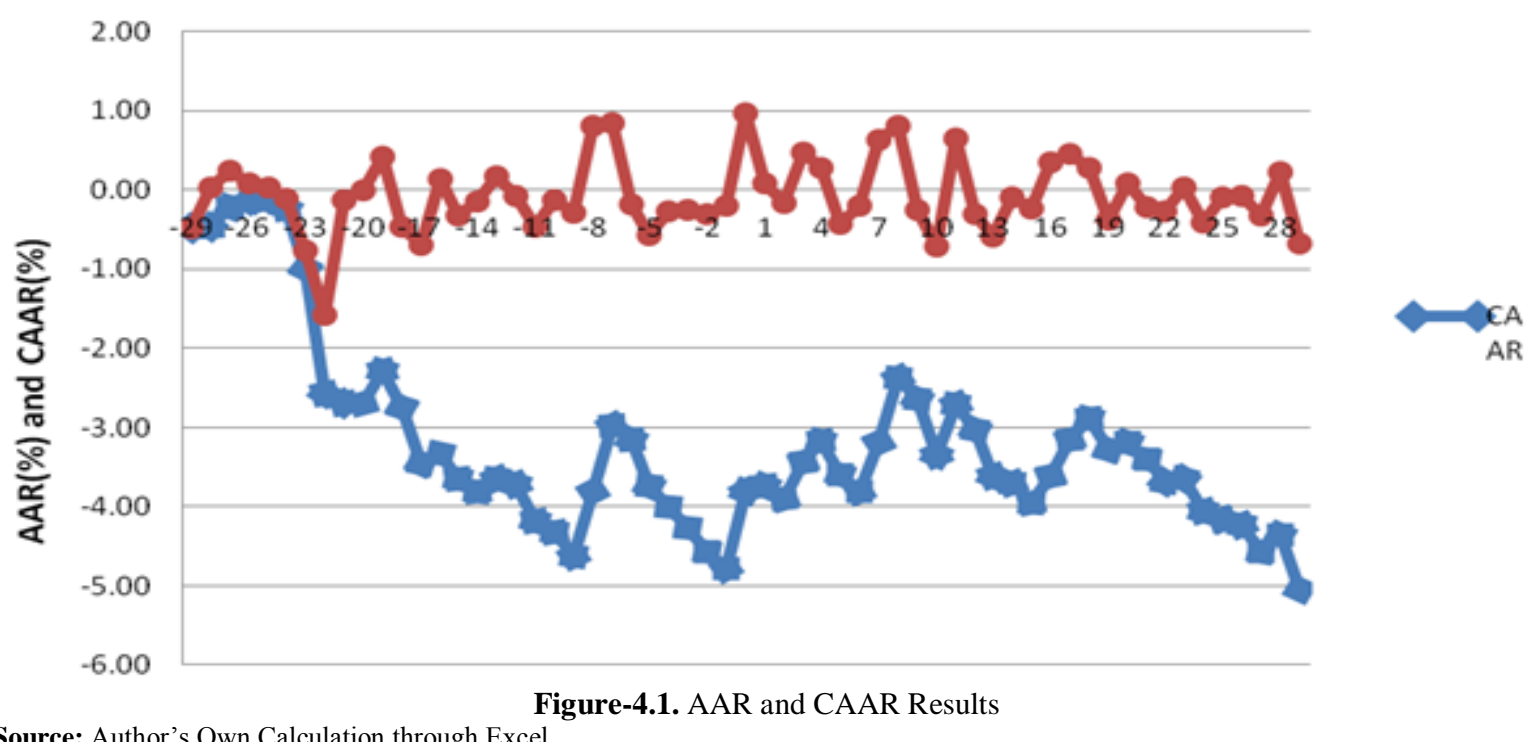

Source: Author's Own Calculation through Excel. 